\title{
Basic life support and advanced cardiac life support knowledge and skills among medical interns before and after a training workshop
}

\section{Wiedza i umiejętności stażystów medycznych w zakresie podstawowych i zaawansowanych zabiegów resuscytacyjnych przed warsztatami szkoleniowymi i po nich}

\author{
Arash Forouzann1, Hasan Barzegari², Mahnaz Attari³, Ali Delirrooyfard² \\ ${ }^{1}$ Department of Emergency Medicine, Imam Khomeini Hospital, Ahvaz Jundishapur University of Medical Sciences, Ahvaz, Iran \\ 2Department of Emergency Medicine, Ahvaz Jundishapur University of Medical Sciences, Ahvaz, Iran \\ ${ }^{3}$ Student Research Committee, Ahvaz Jundishapur University of Medical Sciences, Ahvaz, Iran
}

Medical Studies/Studia Medyczne 2020; 36 (1): 1-5 DOI: https://doi.org/10.5114/ms.2020.94081

Key words: emergency department, basic life support, advanced cardiac life support, cardiopulmonary resuscitation questionnaire.

Słowa kluczowe: oddział ratunkowy, podstawowe zabiegi resuscytacyjne, zaawansowane zabiegi resuscytacyjne, kwestionariusz dotyczący resuscytacji krążeniowo-oddechowej.

\begin{abstract}
Introduction: Effective cardiopulmonary resuscitation can increase the survival of patients with cardiopulmonary arrest. Aim of the research: To investigate the basic life support and advanced cardiac life support knowledge and skills of medical interns at Ahvaz Jundishapur University of Medical Sciences before and after a training workshop.

Material and methods: This study was conducted in 2017-2018 at Ahvaz Jundishapur University of Medical Sciences before and after a training workshop. Data were collected using a questionnaire with 18 items including 11 basic knowledge and seven advanced knowledge items, which assessed the students' knowledge of the latest guidelines by the American Heart Association on cardiovascular resuscitation, before and after a training workshop.

Results: A total of 55 students took part in the study. The mean score in the basic skills part increased significantly from 9.16 to $17.75(p<0.001)$. In the advanced cardiac life support group, the interns' score increased significantly from $8.88 \pm 4.66$ before the workshop to $14.81 \pm 3.11$ afterwards $(p<0.001)$, comprising a statistically significant difference $(p<0.001)$. Conclusions: The knowledge and skills of the interns' scores increased significantly after the workshop.

\section{Streszczenie}

Wprowadzenie: Skuteczna resuscytacja krążeniowo-oddechowa może zwiększyć przeżycie pacjentów z zatrzymaniem krążenia.

Cel pracy: Ocena wiedzy na temat podstawowych i zaawansowanych zabiegów resuscytacyjnych oraz umiejętności stażystów medycznych na Uniwersytecie Nauk Medycznych Ahvaz Jundishapur przed warsztatami szkoleniowymi i po nich. Materiał i metody: Badanie przeprowadzono w latach 2017-2018 na Uniwersytecie Nauk Medycznych Ahvaz Jundishapur przed warsztatami szkoleniowymi i po nich. Dane zebrano za pomocą kwestionariusza zawierającego 18 pozycji, w tym 11 dotyczących podstawowych informacji i 7 dotyczących zaawansowanych informacji, dzięki którym oceniano wiedzę studentów na temat najnowszych wytycznych American Heart Association dotyczących resuscytacji sercowo-naczyniowej przed warsztatami szkoleniowymi i po nich.

Wyniki: W badaniu wzięło udział 55 studentów. Średni wynik w części dotyczącej podstawowych umiejętności znacznie wzrósł z 9,16 do 17,75 ( $p<0,001)$. W części dotyczącej zaawansowanych zabiegów resuscytacyjnych wynik stażystów znacznie wzrósł z 8,88 $\pm 4,66$ przed warsztatami do $14,81 \pm 3,11$ po nich $(p<0,001)$, co stanowi istotną statystycznie różnicę $(p<0,001)$

Wnioski: Wiedza i umiejętności stażystów znacznie się zwiększyły po warsztatach szkoleniowych.
\end{abstract}




\section{Introduction}

Effective cardiopulmonary resuscitation (CPR) can increase the survival of patients with cardiopulmonary arrest (CPA). CPA refers to the sudden cessation of breathing or blood circulation in patients (except for patients in the end or advanced stages of chronic diseases and cancer) [1]. The World Health Organisation (WHO) estimates that cardiovascular diseases are the main cause of death among non-communicable diseases; according to their 2012 report, 17.5 million people died of CPA during the reported year, i.e. $46 \%$ of all deaths caused by non-communicable diseases [2]. According to statistics published by the American Medical Association (AMA), 300,000 people die due to cardiovascular diseases every year in the United States. Meanwhile, $20 \%$ to $30 \%$ of these deaths could have been prevented by proper cardiopulmonary resuscitation (CPR) [3]. The American Heart Association (AHA) recommends the use of a chain of survival for all patients requiring CPR. The links of this chain include the rapid identification of the patient requiring CPR, rapid and non-delayed CPR, the rapid and timely use of a defibrillator, advanced resuscitation procedures, and post-cardiac resuscitation care [4].

In the basic life support (BLS) stage, the main goal is to provide adequate blood circulation and ensure open airways and adequate ventilation for blood supply to the vital organs. BLS is a key part of the resuscitation process, which improves the chances of survival in patients with cardiac arrest $[5,6]$.

In the advanced cardiac life support (ACLS) stage, the procedures follow the same order as BLS, but more advanced equipment is used. Therefore, ACLS is the continuation of BLS. In general, these procedures purport to improve cardiac output and the supply of oxygen to the tissues, which can be achieved by chest compression artificial ventilation and the administration of medications [7].

In the United States, BLS training has been recommended for all health care professionals since 1966 [8]. Previous studies show that CPR performed by highly-skilled and trained people with the least delay reduces mortality rates [9]. The most common causes of CPR failure include the lack of knowledge of cardiac resuscitation algorithms, poor CPR team leadership and non-skilled personnel, the lack of adequate harmony among the resuscitation team members during CPR, and poor accountability on the part of the personnel [8].

Several studies have shown the effect of the involvement of trained people on the resuscitation process. Just involving a person with more skills, based on the results of one of these studies, can have a tremendous effect on the resuscitation process [10]. Given the value of CPR, a recent study in Iran found that only $9.7 \%$ of medical treatment workers had the skills needed in this regard [11]. In Iran, although BLS training has been increasingly added to the curricula of medical and nursing students, the knowledge of proper BLS techniques among the medical personnel remains questionable.

\section{Aim of the research}

The present study aims to investigate the basic and advanced cardiac life support knowledge and skills of the medical interns of Ahvaz Jundishapur University of Medical Sciences before and after a training workshop.

\section{Material and methods}

\section{Study design}

This study was conducted at the Ahvaz Jundishapur University of Medical Sciences in 2017-2018 to examine the BLS and ACLS knowledge and skills of medical interns before and after a training workshop. This study was conducted in accordance with the Declaration of Helsinki for research involving human subjects and received the approval of the Ethics Committee of Ahvaz Jundishapur University of Medical Sciences, Iran (IR.AJUMS.REC.1397.262).

The study inclusion criterion was being a medical intern at Ahvaz Jundishapur University of Medical Sciences, and the exclusion criterion was a written note of unwillingness to take part in the study.

\section{Participants}

The participating interns were asked to take part in the pretest, which included completing a questionnaire designed according to the AHA pretest [12]. Then, the interns' practical skills were assessed and scored in different areas by three emergency medicine professionals.

The knowledge questionnaire contained 18 items (11 on basic knowledge and seven on advanced knowledge) and assessed the students' knowledge of the latest AHA guidelines on cardiovascular resuscitation. The items about basic knowledge included the order of procedures in different scenarios, the chest compression ventilation ratio, the site and time of pulse measurement in adults, the position of the hands during chest compression, the airway opening procedures, saving a drowned person, the treatment of patients with decreased consciousness level, measures taken by ordinary people to deal with cardiopulmonary arrest, the use of an automated external defibrillator (AED), and checking the carotid pulse during resuscitation. In the advanced knowledge part, the students had to answer questions such as the causes of cardiopulmonary arrest, medications used in CPR, indications for prolonged resuscitation, procedures to deal with special patients, and para-clinical findings during CPR. 


\section{Variables and data measurement}

In the skills assessment part, basic skills were assessed in a part containing the following five items: observing the sequence of CPR, effective compression and ventilation, observing the appropriate chest compression ventilation ratio, and the proper use of AED. The advanced skills were assessed in four parts: leadership responsibilities (three items on the quality control of CPR and the division of duties), management of ventricular fibrillation and pulse-free ventricular tachycardia (six items on diagnosis, required procedures, and medications), management of asystole (four items on diagnosis, required procedures, and medications), and post-cardiac arrest care (three items on the detection of ROS symptoms, ensuring the measurement of blood pressure and 12-lead ECG, monitoring oxygen saturation (O2Sat), expressing the need for orotracheal intubation and capnography, requesting tests and considering hypothermia therapy. The interns performed BLS under the supervision of three emergency medicine professionals who were official tutors of the AHA.

The next stage included a briefing on advanced CPR theory followed by viewing an AHA training video. One of the interns was chosen as the group leader, who delegated responsibility to each team member for the different sections, including monitoring, chest compression, airway, defibrillator and medications, and the recording of events. Then, a scenario was proposed by the course tutor, and the performances of the group leader and other team members were assessed based on how they responded to the scenario. At the end of the workshop, the questionnaires were re-distributed among the interns to complete and return, and their knowledge was assessed again.

\section{Statistical analysis}

To analyse the quantitative data, mean and median were used to describe the centre of the data, and standard deviation and interquartile range were used to describe the dispersion of data. The normal distribution of the data was assessed using the KolmogorovSmirnov test and Q-Q plots. Data were analysed using the Wilcoxon and $\chi^{2}$ tests at a significance level of 0.05 . All the tests were performed in SPSS (v22).

\section{Results}

A total of 55 interns undergoing an acute medicine course took part in the study. In the BLS skills part, their mean score increased from 9.16 to 17.75. The comparison of the results showed that the interns had a mean score (mean \pm SD) of $9.75 \pm 3.45$ in the BLS knowledge before the workshop, which increased to $14.61 \pm 2.75$ after the workshop, which comprises a significant difference $(p<0.001)$ (Table 1$)$.

In the ACLS knowledge part, the interns had a score of $8.88 \pm 4.66$ in the pretest, which increased significantly to $14.81 \pm 3.11$ after taking part in the course $(p<0.001)$. The comparison of the results showed that, in the BLS skills part, the interns had a mean score of $9.16 \pm 4.6$ before the workshop, which increased to $17.75 \pm 2.75$ afterwards, comprising a significant difference $(p<0.001)$ (Table 1$)$.

In the ACLS skills part, the interns' score increased significantly from $9.93 \pm 4.5$ before taking part in the course to $17.16 \pm 2.29$ afterwards. There was a significant relationship $(p<0.001)$ and an agreement rate of $83.6 \%$ in BLS and ACLS knowledge after the workshop (Table2). There was a significant relationship after the course between the BLS and ACLS skills scores $(p<0.028)$, showcased by an $83.6 \%$ agreement rate (Table 3 ).

Table 1. Knowledge and skills for BLS and ACLS before and after training workshops

\begin{tabular}{|lccc|}
\hline Variables & Before training workshops & After training workshops & $P$-value \\
Knowledge of BLS, mean \pm SD & $9.75 \pm 3.45$ & $14.61 \pm 2.75$ & $<0.001$ \\
Knowledge of ACLS, mean \pm SD & $8.88 \pm 4.66$ & $14.81 \pm 3.11$ & $<0.001$ \\
Skills of BLS, mean \pm SD & $9.16 \pm 4.6$ & $17.75 \pm 2.75$ & $<0.001$ \\
Skills of ACLS, mean \pm SD & $9.93 \pm 4.5$ & $17.16 \pm 2.29$ & $<0.001$ \\
\hline
\end{tabular}

Table 2. A comparative study of student learning in BLS and ACLS knowledge, $n$ (\%)

\begin{tabular}{|lcccc|}
\hline BLS knowledge & \multicolumn{3}{c|}{ ACLS knowledge } & $\begin{array}{c}\text { Percentage } \\
\text { of agreement }\end{array}$ \\
\cline { 2 - 4 } Regres & Regress & No change & Progress & $1(1.8)$ \\
No change & 0 & $1(1.8)$ & $3(5.45)$ & 83.6 \\
Progress & $2(3.63)$ & $2(3.63)$ & $44(80)$ & $<.001$ \\
\hline
\end{tabular}


Table 3. A comparative study of student learning in BLS and ACLS skills, $n$ (\%)

\begin{tabular}{|lccccc|}
\hline BLS knowledge & \multicolumn{3}{c}{ ACLS knowledge } & $\begin{array}{c}\text { Percentage } \\
\text { of agreement }\end{array}$ & $P$-value \\
\cline { 2 - 4 } Regress & Regress & No change & Progress & & 0.028 \\
No change & $1(1.8)$ & 0 & 0 & 83.6 & \\
\hline Progress & $1(1.8)$ & $1(1.8)$ & $4(7.27)$ & & \\
\hline
\end{tabular}

\section{Discussion}

The present study showed that the BLS and ACLS knowledge and skills of the senior and junior students of Jundishapur University of Medical Sciences were not acceptable, and the mean scores obtained in all the parts assessed fell below the midrange score. The present study confirms the results obtained in studies conducted by Chandrasekaran et al [13], Saffari et al. [14], and Plagisou et al. [15] regarding the poor performance of health professionals and medical students regarding low CPR knowledge and skills.

This study also showed that teaching the principles of BLS and ACLS knowledge and skills through workshops improves the performance of medical interns in all the assessed domains significantly $(p<0.001)$. These results agree with the results of previous studies conducted in Iran by Bakhsha and Behnampour [16] and Vahabi et al. [17], as well as foreign studies, such as the one by Mellor and Woollard [18]. Although, similar to the study by Saffari et al. [14], the students' mean score of ACLS skills improved compared to their other scores in this study, unlike Saffari's study, this improvement did not reach significance levels. In the present study, participation in the training course exerted the greatest effect on the students' BLS skills, and more than half of them obtained the full score after taking part in the test, which led to a median of 20 (full score) in this part.

The present study showed that improvement in one of the BLS or ACLS parts of knowledge and skills has a direct relationship with the other part, which implies that identifying and retraining students who have failed in one of the parts of knowledge or skills can contribute to their better performance in all the parts.

The present study showed that none of the senior or junior interns had taken part in BLS or ACLS workshops about dealing with patients with CPA, and they had not received similar formal training either. Given that these skills and knowledge are associated with the stressful situations that medical students will experience, this issue appears to need more attention, so that the deficiencies can be resolved.

The present study showed that the knowledge and skills of senior and junior students were poor and ineffective, and given that adequate knowledge in this field can save many patients' lives, and since doctors are the first line of treatment for CPA patients and as such should be able to manage the critical conditions of a CPA case, formal training programs should be incorporated into medical curricula. Moreover, given that one of the objectives of BLS is the universal training of life-saving techniques in such situations, not only medical students but also all the students entering medical schools (followed by the entire public) should benefit from such trainings. More effective and formal efforts should be taken for such training.

Based on the results of a study conducted by Smith et al. [9], who had argued that the CPR knowledge and skills of health professionals diminish significantly over time, it seems that the efforts to train students or other groups of the society should be periodically repeated in order to have the required effectiveness.

\section{Conclusions}

According to the present study, the knowledge and skills of the interns' score increased significantly after workshop. Moreover, the efforts to save the lives of cardiovascular arrest patients form part of the basic skills that should be learned by all medical students. These skills and knowledge tend to diminish over time, and their training should be provided by official institutions in lower school years, and regular retraining should also form part of the students' curricula.

\section{Conflict of interest}

The authors declare no conflict of interest.

\section{References}

1. Murdock DB. Perioperative cardiopulmonary arrest competencies. AORN J 2013; 98: 116-130.

2. WHO. NCD mortality and morbidity: World Health Organization 2018 [Available from: https:/www.who.int/ gho/ncd/mortality_morbidity/en/.

3. Khoshbaten M, Soleimanpour H, Ala A, Shams Vahdati S, Ebrahimian K, Safari S, Golzari SE, Salek Ranjbarzadeh F, Mehdizadeh Esfanjani R. Which form of medical training is the best in improving interns' knowledge related to advanced cardiac life support drugs pharmacology? an educational analytical intervention study between electronic learning and lecture-based education. Anesth Pain Med 2014; 4: e15546.

4. Powers WJ, Rabinstein AA, Ackerson T, Adeoye OM, Bambakidis NC, Becker K, Biller J, Brown M, Demaerschalk BM, Hoh B, Jauch EC, Kidwell CS, Leslie-Ma- 
zwi TM, Ovbiagele B, Scott PA, Sheth KN, Southerland AM, Summers DV, Tirschwell DL; American Heart Association Stroke Council. 2018 guidelines for the early management of patients with acute ischemic stroke: a guideline for healthcare professionals From the American Heart Association/American Stroke Association. Stroke 2018; 49: e46-e110.

5. Nolan JP. Basic life support. Curr Opin Anaesthesiol 2008; 21: 194-199.

6. Forouzan A, Verki MM, Khabazipour A, Ahmadi K. Basic Life Support awareness among resident doctors, medical students, nursing experts, health care providers, and their assistants in Southwest Iran. Medical Studies 2018; 34: 203-210.

7. Thorne CJ, Lockey AS, Kimani PK, Bullock I, Hampshire S, Begum-Ali S, Perkins GD; Advanced Life Support Subcommittee of the Resuscitation Council (UK). e-Learning in advanced life support - what factors influence assessment outcome? Resuscitation 2017; 114: 83-91.

8. Jack HE, Warren KE, Sundaram S, Gheihman G, Weems J, Raja AS, Miller ES. Making naloxone rescue part of basic life support training for medical students. AEM Educ Train 2018; 2: 174-177.

9. Smith KK, Gilcreast D, Pierce K. Evaluation of staff's retention of ACLS and BLS skills. Resuscitation 2008; 78: 59-65.

10. Taffet GE, Teasdale TA, Luchi RJ. In-hospital cardiopulmonary resuscitation. JAMA 1988; 260: 2069-2072.

11. Mahmoodpoor A, Soleimanpour H, Nia KS, Panahi JR, Afhami M, Golzari SE, Majani K. Sensitivity of palm print, modified mallampati score and 3-3-2 rule in prediction of difficult intubation. Int J Prev Med 2013; 4: 1063-1069.

12. Panchal AR, Berg KM, Hirsch KG, Kudenchuk PJ, Del Rios M, Cabañas JG, Link MS, Kurz MC, Chan PS, Morley PT, Hazinski MF, Donnino MW. 2019 American Heart Association focused update on advanced cardiovascular life support: use of advanced airways, vasopressors, and extracorporeal cardiopulmonary resuscitation during cardiac arrest: an update to the American Heart Association guidelines for cardiopulmonary resuscitation and emergency cardiovascular care. Circulation 2019; 140: e881-e894.

13. Chandrasekaran S, Kumar S, Bhat SA, Saravanakumar, Shabbir PM, Chandrasekaran V. Awareness of basic life support among medical, dental, nursing students and doctors. Indian J Anaesth 2010; 54: 121-126.

14. Saffari M, Amini N, Pakpour AH, Sanaeinasab H. Assessment the medical sciences students knowledge and skill about basic cardiopulmonary resuscitation (CPR) in accidents and disasters. Iran J Health Educ Health Promotion 2013; 1: 41-50.

15. Plagisou L, Tsironi M, Zyga S, Moisoglou I, Maniadakis N, Prezerakos P. Assessment of nursing staff's theoretical knowledge of cardiovascular resuscitation in an NHS public hospital. Hellenic J Cardiol 2015; 56: 149-153.

16. Bakhsha F, Behnampour N. The effect of CPR training on knowledge of nurses working in the hospitals affiliated to Golestan University of Medical Sciences. J Gorgan Univ Med Sci 2007; 8: 46-49.

17. Vahabi S, Alishahi F, Sheikhi E, Anbari K. The effectiveness of cpr training during anesthesia internship rotation on improvement of interns, knowledge and clinical skills of Lorestan University of Medical Sciences. Yafte 2015; 17: 32-41.

18. Mellor R, Woollard M. Skill acquisition by health care workers in the Resuscitation Council (UK) 2005 Guidelines for Adult Basic Life Support. Int Emerg Nurs 2010; 18: 61-66.

\section{Address for correspondence}

Assist. Prof. Ali Delirrooyfard

Department of Emergency Medicine

Ahvaz Jundishapur University of Medical Sciences

Ahvaz, Iran

E-mail: adelir2891@gmail.com 